\title{
Halina Bieluk
}

Białystok

\section{Walka o prawa obywatelskie - niedokończona misja Johna F. Kennedy'ego?}

Na okres trwania administracji Johna F. Kennedy'ego przypadła setna rocznica podpisania Proklamacji Emancypacji, znosząca niewolnictwo Murzynów¹. Wydawać by się mogło, że sto lat to wystarczająco dużo czasu, by wprowadzić istotne zmiany zrównujące czarnych i białych Amerykanów w prawach obywatelskich. Można było mieć takie oczekiwania, zwłaszcza że zmiany te doskonale korespondowałyby z ideą misji, która od początków państwa amerykańskiego wpisana była w jego historię. Niestety, mimo upływu kolejnych dekad, nie odnotowano w tej kwestii zasadniczego postępu. Zarówno pierwsza, jak i druga wojna światowa niosły ze sobą pewną szansę na polepszenie bytu czarnych Amerykanów, którzy służyli swojej ojczyźnie, podobnie jak biali obywatele. Wtedy to właśnie wielu przedstawicieli ludności murzyńskiej zostało żołnierzami², inni natomiast znaleźli zatrudnienie w przemyśle zbrojeniowym. Jednak po zakończeniu wojny czarni obywatele Stanów Zjednoczonych nie tylko nie mogli liczyć na jakikolwiek postęp w kwestii uzyskania praw obywatelskich, ale spotykali się z wrogością, a niekiedy wręcz agresją ze strony białych. Gubernator stanu Georgia wygrał wybory dzięki zapewnieniu, że ,żaden Murzyn nie będzie głosował w Georgii przez następne cztery lata"3, a policja w Aiken, w Południowej Karolinie, nie zawahała się przed wydłubaniem oczu czarnemu sierżantowi, który zaledwie trzy godziny wcześniej został zwolniony z wojska ${ }^{4}$. W odpowiedzi na ten i inne, równie wstrząsające raporty, docierające do Harry’ego S. Trumana, w grudniu 1946 roku ustanowił on Prezydencki Komitet Praw Obywatelskich (President's Committee on Civil Rights). W 1948 roku wydał dwa rozporządze-

\footnotetext{
1 Proklamacja Emancypacji podpisana została 1 stycznia 1863 roku.

2 Czarni Amerykanie walczyli we własnych jednostkach, gdyż w wojsku obowiązywała segregacja.

3 M. B. Norton, D. F. Katzman, P. D. Escott, H. P. Chudacoff, T. G. Paterson, W. M. Tuttle, Jr., A People and a Nation, Boston-Toronto, Houghton Mifflin Company, 1994, s. 861.

4 Ibidem.
} 
nia mające na celu desegregację instytucji życia publicznego. Pierwsze z nich dotyczyło sprawiedliwego zatrudnienia i powołało do życia Radę do Spraw Zatrudnienia przy Komisji Administracji Państwowej (Employment Board of the Civil Service Commission), która miała za zadanie rozpatrywanie skarg dotyczących dyskryminacji rasowej w dziedzinie zatrudnienia. Drugie rozporządzenie wprowadzało desegregację w siłach zbrojnych, a w celu nadzorowania tego procesu utworzyło Komitet do Spraw Równości Traktowania i Możliwości Awansu w Siłach Zbrojnych (Committee on Equality of Treatment and Opportunity in the Armed Services) $)^{5}$. Rozporządzenia wprowadzone przez Trumana stanowiły istotny krok w dążeniu do zrównania w prawach czarnych i białych obywateli Stanów Zjednoczonych, jednak w sposób zasadniczy nie wpłynęły na poprawę bytu przeciętnego czarnego Amerykanina z Południa. Lata pięćdziesiąte również nie przyniosły istotnych zmian w tej kwestii. Murzyni ze stanów południowych żyli w świecie, gdzie wszystko, poczynając od szkół poprzez środki transportu, plaże, aż po toalety publiczne, podlegało segregacji. Tylko nieliczni z nich mogli głosować 6 . W miejscach publicznych biały czarnemu nie podawał ręki i nie zdejmował nakrycia głowy w jego obecności, choć tamten zobowiązany był to uczynić. Do Murzynów nie zwracano się „Mr.”, „Mrs.” czy „Miss”, nazywając przedstawicieli płci męskiej „boy”, „George” lub „Jack”, a kobiety „Aunt” lub ich imieniem 7 . Jednym słowem, dyskryminacja rasowa na Południu od lat pozostawała w niezmienionej formie.

W tych okolicznościach nieuniknione były masowe migracje czarnej ludności na Północ. Zapoczątkowane one zostały w latach czterdziestych dwudziestego wieku, osiągając największe nasilenie w latach pięćdziesiątych i sześćdziesiątych, utrzymując się aż po lata siedemdziesiąte. Ze statystyk wynika, że pomiędzy rokiem 1940 a 1970 z Południa wyemigrowało około 4,5 miliona czarnych Amerykanów, którzy osiedlili się w wielkich miastach na Północy, gdzie poszukiwali pracy $\mathrm{w}$ przemyśle ${ }^{8}$. Jednak nawet na Północy, Murzyni byli wyraźnie dyskryminowani w takich kwestiach, jak: zatrudnienie, możliwość awansu czy też wysokość płacy. Bezrobocie wśród czarnych było dwa razy większe niż wśród białych. Mimo stale poprawiającej się sytuacji ekonomicznej kraju, ponad połowa

5 The Library of Congress [LC], Manuscript Collection, Executive Order No. 9981 establishing the President's Committee on Equality of Treatment and Opportunity in Armed Services, July 26, 1948.

6 R. Harris, Jr., Teaching African-American History, New York-Oxford, Oxford University Press, 1992, s. 51-64.

7 J. T. Patterson, Grand Expectations. The United States 1945-1974, New York-Oxford, Oxford University Press, 1997, s. 381.

8 Dane na temat migracji czarnej ludności w Stanach Zjednoczonych w latach 1940-1970 zostały zaczerpnięte z: M. B. Norton, D. F. Katzman, P. D. Escott, H. P. Chudacoff, T. G. Paterson, W. M. Tuttle, Jr., A People..., s. 940. 
czarnych obywateli Stanów Zjednoczonych żyła w biedzie nawet w połowie lat pięćdziesiątych. Dla porównania, w tym samym czasie w skrajnym ubóstwie żyło 20-25\% białych obywateli Stanów Zjednoczonych'.

Nic więc dziwnego, że to właśnie na lata pięćdziesiąte przypada początek walki czarnych Amerykanów o prawa obywatelskie. Nacisk w tej walce położono na dwie kwestie - mieszkalnictwo oraz edukację. Ludność murzyńska zamieszkiwała najuboższe, najsłabiej zagospodarowane dzielnice. Dorośli, jeśli w ogóle byli w stanie znaleźć zatrudnienie, wykonywali najcięższe i najmniej płatne prace, a ich dzieci uczęszczały do najsłabiej dofinansowywanych szkół. W stanie Karolina Południowa wydawano trzy razy więcej na „białe” niż na „czarne” szkoły, a na transport do nich, analogicznie sto razy więcej. W konsekwencji, biali uczniowie mogli sobie wybrać dobrą placówkę edukacyjną nawet w odległej dzielnicy, bo dowożone były do niej specjalnym autobusem, podczas gdy ich czarni rówieśnicy skazani byli na szkołę w najbliższym sąsiedztwie. W stanie Mississippi rok szkolny w murzyńskich dzielnicach był skrócony, nauczycielom płacono mniej niż w szkołach przeznaczonych dla białych dzieci, a książki, z których nauczano, przekazywane były z białych placówek wtedy, gdy te już ich nie potrzebowały ${ }^{10}$. Jednym słowem, sytuacja czarnego ucznia na południu USA była dramatyczna, a bez szans na lepsze wykształcenie, nie było możliwości przekroczenia granic czarnych dzielnic.

Po ukończeniu kilku klas w szkołach o niskim poziomie, młodzi ludzie powielali schematy z życia swoich rodziców. Biali Amerykanie z Południa, pragnąc zapobiec awansowi społecznemu czarnej ludności, skutecznie blokowali jej dostęp do edukacji na odpowiednim poziomie. $Z$ jednej strony gwarantowało to pozostanie czarnych „na swoim miejscu”, z drugiej strony nie burzyło stereotypu Jima Crowa ${ }^{11}$, do którego tak bardzo przywiązani byli południowcy od czasów wojny secesyjnej. Nic więc dziwnego, iż za wszelką cenę pragnęli oni utrzymać istniejący stan rzeczy.

Lata pięćdziesiąte przyniosły jednak zasadnicze zmiany w tej kwestii. Czarni Amerykanie postanowili walczyć również o zrównanie szans w dziedzinie edukacji, a tym samym zapewnienie sobie lepszych perspektyw na przyszłość i okazali się w tym skuteczni. Prawdziwie przełomowym wydarzeniem okazało się wydanie orzeczenia Sądu Najwyższego z 17 maja 1954 roku w sprawie Brown vs. Board of Education of Topeka. Stwierdzało ono, że zasada „oddzielni, ale

\footnotetext{
9 W. Harris, The Harder We Run: Black Workers Since the Civil War, New York-Oxford, Oxford University Press, 1982, s. 123-189.

10 Ibidem.

11 Jim Crow był postacią fikcyjną, wymyśloną w latach trzydziestych dziewiętnastego wieku. Przedstawiany był jako stary, utykający, niezręczny murzyński niewolnik, zawdzięczający wszystko, co ma swemu białemu panu. Jim Crow w oczach białych stanowił uosobienie wszelkich negatywnych cech czarnych Amerykanów.
} 
równi”, obowiązująca w Stanach Zjednoczonych od lat dziewięćdziesiątych dziewiętnastego wieku' ${ }^{12}$, była sprzeczna z Konstytucją. W 1955 roku Sąd Najwyższy nakazał desegregację szkół, lecz nie wszędzie i nie od razu weszła ona w życie. Władze wielu południowych stanów wolały raczej zamknąć szkoły publiczne, niż zezwolić na wspólne uczęszczanie do nich białych i czarnych dzieci.

Prezydent Dwight D. Eisenhower zajął postawę dość ambiwalentną w kwestii desegregacji szkół - choć zasadniczo popierał ją, sprzeciwiał się wprowadzaniu jej poprzez stosowanie przymusowego prawa federalnego. Utrzymywał, że powinna ona nastąpić w wyniku ,inicjatywy lokalnej”. Obawiał się również, że partia republikańska może stracić poparcie na Południu w wyniku zbyt szybkiego, administracyjnego wprowadzenia desegregacji placówek edukacyjnych. W rozmowie z Prezesem Sądu Najwyższego, Earlem Warrenem, prezydent stwierdził, że: „Południowcy to nie są źli ludzie. Martwią się po prostu, że ich śliczne małe dziewczynki będą musiały siedzieć [w ławce] z przerośniętymi Murzynami”" ${ }^{13}$. Wypowiedź Dwighta D. Eisenhowera wywołała ogromne zdumienie Earla Warrena. Jednak we wrześniu 1957 roku Eisenhower zają jednoznaczne stanowisko, gdy w stolicy Arkansas, Little Rock, użył wojska w celu umożliwienia wejścia do Central High School dziewięcioosobowej grupie czarnych uczniów. Sam fakt dostania się do środka budynku nie rozwiązywał jednak problemu. Istnieją dokumenty mówiące o nieukrywanej wrogości nie tylko ze strony białych kolegów, lecz również nauczycieli w stosunku do czarnych uczniów. Najwyraźniej, dyrekcja szkoły traktowała ich obecność jako sytuację przejściową, nie zezwalając im na pełny udział w życiu szkoły. Jedną z uczennic, Minnie Jean Brown odsunięto od przygotowań do spektaklu bożonarodzeniowego. Dyrektor wyjaśnił jej, że: „Kiedy definitywnie zostanie postanowione, że Murzyni będą chodzić do tej szkoły razem z białymi i kiedy oddziały federalne zostaną usunięte, wtedy będziecie mogli uczestniczyć we wszystkich zajęciach"14. Dyskryminacja czarnych uczniów nie ograniczała się do odsunięcia ich na margines życia szkoły. Sytuacja była znacznie poważniejsza - kopano ich, opluwano i znęcano się nad nimi w każdy możliwy sposób. Nie mogło być mowy o pokojowym współistnieniu białych i czarnych uczniów ${ }^{15}$.

Desegregacja szkół nie była jedynym zadaniem z dziedziny praw obywatelskich, z którym miała się zmierzyć administracja Dwighta D. Eisenhowera. 1 grudnia 1955 roku w Montgomery, w Alabamie, Murzynka Rosa Parks, jadąc

12 Zasada została ustanowiona w sprawie Plessy v. Ferguson w 1896 roku.

13 Dwight D. Eisenhower cytowany w: M. B. Norton, D. F. Katzman, P. D. Escott, H. P. Chudacoff, T. G. Paterson, W. M. Tuttle, Jr., A People..., s. 875.

14 LC, NAACP Collection, Manuscript Division, list Daisy Bates do Roya Wilkinsa na temat traktowania czarnych uczniów w Central High School w Little Rock, 17 grudnia 1957.

15 Ibidem. 
z pracy autobusem, zajęła miejsce w jego przedniej części i odmówiła odstąpienia go białemu mężczyźnie ${ }^{16}$. Kierowca wezwał policję, która aresztowała ją za zakłócanie porządku publicznego. Był to przełomowy moment w walce czarnej ludności o desegregację środków transportu. Od tej pory nazwisko Rosy Parks, która stała się później postacią legendarną, niezmiennie kojarzyło się z walką o prawa obywatelskie. W odpowiedzi na incydent z 1 grudnia 1955 roku czarni aktywiści, z Martinem Lutherem Kingiem na czele, zorganizowali bojkot autobusów, trwający ponad rok. W jego wyniku, 21 grudnia 1956 roku zniesiono segregację rasową w środkach transportu publicznego. Rok 1957 przyniósł kolejną zmianę na lepsze w życiu przeciętnego czarnego obywatela Stanów Zjednoczonych. - utworzono U.S. Commission on Civil Rights (Amerykańską Komisję Praw Obywatelskich), która miała zająć się wszelkimi przejawami dyskryminacji rasowej, w tym również, w zakresie praw wyborczych. Komisja zaleciła likwidację praktyk lokalnych, na skutek których zaledwie 25\% czarnej ludności stanów południowych brało udział w głosowaniu. Kwestia ta została częściowo uregulowana 6 maja 1960 roku przez Civil Rights Act of 1960 (Ustawa o Prawach Obywatelskich z 1960 roku) ${ }^{17}$.

W raporcie tejże komisji z dnia 14 grudnia 1960 roku opublikowane zostały statystyki ujawniające rozmiary dyskryminacji rasowej w Stanach Zjednoczonych. Wynikało z nich, że 57\% budynków zamieszkiwanych przez społeczność murzyńską nie nadawało się do użytku. Wartość nieruchomości znacznie spadała, jeśli czarna rodzina wprowadziła się do domu w sąsiedztwie. Trzeba jednak przyznać, że do zakupu domu przez Murzynów w białej dzielnicy dochodziło jedynie sporadycznie, gdyż nie udzielano im kredytu pod hipotekę. Raport donosił również, iż przeciętny czarny Amerykanin żył o 7 lat krócej niż jego biały rodak, a śmiertelność wśród czarnych noworodków była dwa razy większa niż wśród białych ${ }^{18}$. Dane te były zatrważające. Nie dziwi więc fakt, że czarna społeczność nie ustawała w wysiłkach mających na celu poprawienie swojego bytu.

Do trudnej sytuacji czarnych Amerykanów niejednokrotnie nawiązywał podczas swojej kampanii prezydenckiej John F. Kennedy. Już w pierwszej debacie telewizyjnej z 26 września 1960 roku z Richardem Nixonem kandydat do Białego Domu przyrzekł uchwalenie odpowiednich ustaw o prawach obywatelskich, a następnie wcielenie ich w życie. Podczas swojego wystąpienia stwierdził, że nie spocznie, „zanim każdy Amerykanin nie będzie cieszył się pełnymi prawami

16 Czarni mogli siadać jedynie w tylnej części autobusu i zobowiązani byli ustąpić miejsca białemu, jeśli ten ich o to poprosił.

17 Szerzej o obu ustawach, patrz: K. Michałek, Amerykańskie stulecie. Historia Stanów Zjednoczonych Ameryki 1900-2001, Warszawa, Mada, 2004, s. 292.

18 John F. Kennedy Library [JFKL], Pre-Presidential Papers, Box 912, The 1960 Report by the Civil Rights Commission, December 14, 1960. 
konstytucyjnymi" "19. Wyglądało na to, że walkę o prawa obywatelskie potraktuje jako misję, tym bardziej, że dostrzegał w niej wymiar moralny. Uważam, że koncepcja równości praw, wywodząca się z Konstytucji, zawiera w sobie ważna moralna zasadę mówiaca o tym, że wszyscy sa równi. Zasada ta stanowi podstawę budowy demokracji, twierdził Kennedy. [...] Statystyki wykazuja, że ze względu na kolor skóry, szanse Murzyna na ukończenie college'u, posiadanie domu, zdobycie zawodu, utrzymania pracy sa znacznie mniejsze niz biatego obywatela. Nie powinno to mieć miejsca $w$ demokracji. Dlatego też, chociaż ludzie różniq się talentem, zdolnościami i motywacja, wszyscy powinni mieć jednakowe możliwości rozwijania swoich umiejętności ${ }^{20}$.

W 1960 roku szeroko rozpropagowana została nowa metoda przeciwstawiania się praktykom segregacyjnym, tak zwane „,sit-ins”. Zapoczątkowana w lutym 1959 roku przez czterech czarnych studentów z North Carolina Agricultural and Technical College w Greensboro, często stosowana była nie tylko przez czarną młodzież, ale również przez przywódców ruchu na rzecz praw obywatelskich. To właśnie za „sit-in" w ramach pokojowej demonstracji w jednym z barów w Atlancie, 19 października 1960 roku został aresztowany Martin Luther King, a sześć dni później skazano go na cztery miesiące ciężkich prac. Choć szeroko pisała o tym prasa, Dwight D. Eisenhower nie wyraził zainteresowania sytuacją murzyńskiego przywódcy. W sukurs przyszedł mu dopiero John F. Kennedy i to on właśnie przyczynił się do zwolnienia Kinga za kaucją. Ten przejaw dobrej woli ze strony Kennedy'ego oraz to, że wypowiadał się on pozytywnie o „sit-ins" został dostrzeżony i doceniony przez czarnych Amerykanów. Uwadze ich nie uszedł też fakt, że senator wypowiadał się krytycznie na temat polityki rasowej prowadzonej przez Eisenhowera. Kennedy zarzucał mu na przykład, że prezydent nie zdołał doprowadzić do desegregacji w budownictwie mieszkaniowym, podczas gdy, zdaniem senatora, ten problem można było rozwiązać jednym pociągnięciem pióra ${ }^{21}$. O postawie kandydata partii demokratycznej na prezydenta nie zapomnieli czarni Amerykanie, którzy masowo poparli go podczas listopadowych wyborów.

Choć w mowie inauguracyjnej w dniu 20 stycznia 1961 roku Kennedy zapowiedział położenie kresu dyskryminacji rasowej22, to jednak zadanie było trudne do zrealizowania. W sytuacji, gdy w pierwszej kolejności należało uporać się

19 JFKL, Pre-Presidential Papers, Box 912, Television Debates, pierwsza debata telewizyjna, 26 września 1960 roku.

20 JFKL, The Campaign and the Candidates, NBC-TV Show No. 3, Interview by Chet Huntley and David Brinkley of Senator John F. Kennedy in his home at Hayannis Port, Mass., September 30, 1960, for presentation, October 1, 1960.

21 JFKL, Pre-Presidential Papers, Box 912, Statement by Senator John F. Kennedy on Leadership Conference on Civil Rights, Washington, D.C., August 8, 1960.

22 Public Papers of the Presidents of the United States, John F. Kennedy 1961, January 20 to December 31, 1961, Inaugural Address, United States Printing Office, Washington: 1962, s. 2. 
$\mathrm{z}$ napięciami wiążącymi się z tak istotnymi kwestiami polityki zagranicznej jak zimna wojna, wyścig zbrojeń, nierozwiązany problem kubański oraz walka z Rosją o wpływy w krajach wyzwalających się spod jarzma kolonializmu, prawa obywatelskie musiały zejść na plan dalszy. Wywiązaniu się z obietnic z okresu kampanii prezydenckiej nie sprzyjał również fakt, że Kongres zdominowany był przez konserwatywną koalicję republikanów wspieranych przez demokratów z Południa. Tak więc, za słowami nie poszły czyny. Nie należy jednak upatrywać przyczyn bierności prezydenta jedynie w niesprzyjającym układzie politycznym. Kennedy nie w pełni dostrzegał istotę problemu. Karierę polityczną rozpoczynał w Bostonie, gdzie walka czarnej ludności o prawa obywatelskie nie miała takiego wymiaru jak na Południu. Jedyni czarni, których znał, to ci pracujący jako szoferzy lub w charakterze pomocy domowej. Przyjaciele Kennedych, a wśród nich znany dziennikarz, Arthur Krock, twierdzili, że kwestie dotyczące Murzynów nigdy nie były poruszane w domu Kennedych ${ }^{23}$, a sam prezydent $\mathrm{w}$ czasach, gdy był jeszcze senatorem, nie wykazywał zainteresowania problematyką nierówności społecznej czy sprawami rasowymi. Nic więc dziwnego, że inauguracyjne obietnice potraktował bardziej jako hasła polityczne, niż, jak to wcześniej zapowiadał, moralny obowiązek rozwiązania problemu, czy też misję do wypełnienia.

O zapatrywaniach Kennedy'ego na kwestię praw obywatelskich świadczy incydent, do którego doszło już 6 lutego 1961 roku, gdy przyjmował czarnych dyplomatów z Afryki, którzy przybyli na obrady ONZ. Kiedy skarżyli się oni, że restauracje przy drodze do Waszyngtonu nie chciały ich obsłużyć, prezydent odbył rozmowę z szefem protokołu - Angier Biddle Dukem: Proszę powiedzieć im, zeby tego nie robili - zażądat prezydent. Duke zacząt wyjaśniać, jakie wysitki poczynit w kwestii desegregacji restauracji, lecz Kennedy przerwat mu w pót stowa: Nie to mam na myśli - stwierdzit - Prosze powiedzieć afrykańskim ambasadorom, żeby nie jeździli czterdziestka. To okropna droga. Proszę im powiedzieć, że nigdy nie wpadłbym na to, by jechać samochodem z Nowego Jorku do Waszyngtonu. Powinni byli polecieć samolotem ${ }^{24}$. Sugestia zmiany środka transportu stanowiła obejście, a nie rozwiązanie problemu nierówności społecznej. Prezydent zdawał się jednak tego nie dostrzegać.

Należy przyznać, że nowo wybrany prezydent przedsięwziął pewne kroki, by podkreślić swoje poparcie dla ruchu praw obywatelskich. Zarządził na przykład włączenie czarnych Amerykanów do straży nabrzeżnej. Podczas pierwszego posiedzenia gabinetu, prosił poszczególnych sekretarzy o rozważenie możliwości zatrudnienia Murzynów w swoich departamentach. Podkreślał, iż powinni się oni znaleźć zwłaszcza w służbach zagranicznych, by stworzyć właściwy wizerunek Stanów Zjednoczonych za granicą. Temu właśnie celowi miało służyć miano-

23 J. N. Giglio, The Presidency of John F. Kennedy, University Press of Kansas, 1991, s. 159.

24 John Kennedy cytowany w: J. T. Patterson, Grand Expectations..., s. 475. 
wanie Clifforda R. Whartona na stanowisko ambasadora w Norwegii. Kennedy nominował pięciu czarnych na stanowisko sędziów federalnych, a Thurgooda Marshalla ${ }^{25}$ powołał do Sądu Apelacyjnego. Ważnym posunięciem prezydenta było stworzenie w dniu 6 marca 1961 roku Komitetu do Spraw Równości Zatrudnienia (Committee on Equal Employment Opportunities), na czele którego stanął wiceprezydent Lyndon B. Johnson ${ }^{26}$. W ramach działalności komitetu powstały Plany dla Rozwoju (Plans for Progress), które weszły w życie dzięki zobowiązaniom przedstawicieli wielkich amerykańskich korporacji do popierania równości w zatrudnieniu. Równość ta miała polegać - jak deklarowano na „dostępności miejsc pracy dla wszystkich wykwalifikowanych Amerykanów, niezależnie od ich rasy, religii i koloru skóry"27.

Założenia były szczytne, niestety, nie od razu i nie zawsze udawało się je zrealizować. Tak naprawdę wszystko zależało od samej firmy i prowadzonej przez nią polityki zatrudnienia, która nie zawsze dawała się pogodzić z Planami dla Rozwoju. Duże rozbieżności w liczbie zatrudnionych czarnych pracowników można było dostrzec pomiędzy firmami zlokalizowanymi na północy i tymi na południu kraju - na korzyść firm z północy, oczywiście. Co więcej, podobne zależności wydawały się być normą pomiędzy firmami macierzystymi na północy, a ich filiami na południu ${ }^{28}$.

Wiele firm, pomimo przystąpienia do Planu dla Rozwoju, zatrudniało czarnych tylko wtedy, gdy wiązało się to z wyraźnymi korzyściami finansowymi (na przykład, czarny klient kupował chętniej u czarnego sprzedawcy). Niektórzy pracodawcy uważali, iż wywiązali się ze swoich zobowiązań, ponieważ zatrudnili kilku Murzynów w charakterze sprzątaczy i portierów. Na ogół więc, trudno było mówić o stwarzaniu równych szans zatrudnienia czarnym obywatelom Stanów Zjednoczonych. Były jednak chlubne wyjątki. Do nich należały Lockheed, Western Electric i Goodyear. W tych przedsiębiorstwach Plany dla Rozwoju zostały w pełni zrealizowane. Ogólnie jednak należy stwierdzić, że, jak to ujął Herbert Hill, członek NAACP, „Plany wiązały się z większym rozgłosem niż postępem” 29.

Prezydent nie pozwolił również na rozwiązanie Komisji Praw Obywatelskich, która miała działać jedynie do 1 października 1960 roku. Nie był jednak

\footnotetext{
25 Thurgood Marshall był pionierem w walce o prawa obywatelskie czarnych Amerykanów. The University of Maryland odmówił mu przyjęcia na studia doktoranckie ze względu na jego kolor skóry. Tytuł doktora Marshall otrzymał w the Howard University Law School i od 1938 roku został głównym doradcą prawnym National Association for the Advancement of Colored People (NAACP).

26 LC, Manuscript Collection, Executive Order 10925, establishing the Committee on Equal Employment Opportunities, 6 marca $1961 \mathrm{r}$.

27 Roosevelt Study Center [RSC], Civil Rights during the Kennedy Administration, 1961-1963, Reel 28, Special Report, Plans for Progress: Atlanta Survey.

28 Ibidem.

29 Herbert Hill cytowany w: Ibidem.
} 
gotów do podjęcia radykalnych kroków w ramach tej Komisji. Gdy jej członek, Theodore Hesburgh wskazywał na konieczność przeciwstawienia się takim zjawiskom, jak nieobecność czarnych w na uniwersytetach stanów południowych czy też w Narodowej Gwardii Alabamy, Kennedy zdecydowanie oponował. „Być może jutro będę musiał wysłać Narodową Gwardię Alabamy do Berlina", tłumaczył Hesburghowi, ,i nie chcę, by stało się to w trakcie rewolucji w kraju" "30. Wypowiedź ta wyraźnie określa priorytety Kennedy'ego.

Choć Kennedy’emu nie można odmówić dobrych chęci, jego posunięcia nie zmieniały w sposób zasadniczy położenia czarnej ludności Stanów Zjednoczonych, gdyż to uczynić mogła jedynie odpowiednia ustawa o prawach obywatelskich. Ta z kolei była niemożliwa do uchwalenia, ze względu na zdecydowany opór jej przeciwników w Kongresie. Kennedy nie zdołał również doprowadzić do desegregacji federalnego budownictwa mieszkaniowego, choć wcześniej twierdził, jeszcze za kadencji Dwighta D. Eisenhowera, że sprawę tę można było załatwić jednym pociągnięciem pióra. W nawiązaniu do tej wypowiedzi, na adres Białego Domu zaczęły napływać tysiące piór, żadne z nich nie zostało użyte do podpisania tego ważnego dokumentu. Także w kwestii rejestracji czarnych wyborców Kennedy nie uczynił nic w pierwszym roku swojej administracji. Uważał on, że problemu tego nie należy rozwiązywać na szczeblu federalnym, lecz powinny się nim zająć poszczególne stany.

Tak więc, z perspektywy 1961 roku wyglądało na to, że sytuacja czarnej ludności nie poprawi się w istotny sposób w trakcie administracji Johna Kennedy’ego. Jednak zarówno przywódcy murzyńscy, jak i zwykli czarni obywatele dalecy byli od pogodzenia się ze swoim trudnym położeniem. W 1961 roku zaczęli organizować rajdy wolności. Czarni aktywiści, niejednokrotnie wspierani przez białych, zwykle młodych ludzi z Północy, wsiadali do autobusów w jednym z wielkich miast na Północy, by odbyć podróż na Południe. Po drodze usiłowali doprowadzić do desegregacji dworców autobusowych, zgodnie z ustawą z grudnia 1960 roku, która stwierdzała, że segregacja w tych miejscach jest niezgodna z Konstytucją.

Organizatorzy rajdów, przewidując, że ich uczestnicy spotkają się z agresją ze strony mieszkańców Południa, powiadomili o zamiarze ich organizacji prezydenta, prokuratora generalnego - Roberta Kennedy'ego oraz dyrektora FBI J. Edgara Hoovera. Nie zapewniło to jednak bezpieczeństwa uczestnikom rajdów, których w miastach południowych stanów atakowano pałkami, kijami baseballowymi i łańcuchami od rowerów natychmiast po opuszczeniu przez nich autobusu. Federalna ochrona przybywała zwykle zbyt późno ${ }^{31}$.

30 John Kennedy cytowany w: R. Reeves, President Kennedy. Profile of Power, New York, Simon and Schuster, 1993, s. 60.

31 J. N. Giglio, The Presidency..., s. 165. 
John F. Kennedy skłonny był przyznać, że rajdy odbywały się w słusznej sprawie i oburzony był brutalnością przeciwników desegregacji środków transportu. Oburzenie to miało jednak swoje źródło nie tyle w zwyczajnym ludzkim współczuciu, co w obawie, że zamieszki zaszkodzą wizerunkowi Stanów Zjednoczonych za granicą - zwłaszcza przed szczytem w Wiedniu zaplanowanym na 3-4 czerwca 1961 roku. Amerykański prezydent zdawał sobie z tego sprawę, że $\mathrm{w}$ okresie napięć związanych z zimną wojną i wyścigiem zbrojeń, po porażce w Zatoce Ś wińn $^{32}$, rajdy z pewnością nie przyczynią się do umocnienia jego pozycji w negocjacjach z Nikitą Chruszczowem. W związku z tym, apelował o „ostudzenie zapałów” czarnych Amerykanów w imię interesu państwowego. Jego apel nie spotkał się ze zrozumieniem czarnych obywateli. W ich imieniu wypowiedział się James Farmer, działacz CORE (Congress of Racial Equality), stwierdzając, że studzili oni swoje zapały przez 150 lat. „Jeśli będziemy studzić je dalej, zapadniemy w stan hibernacji”" ${ }^{33}$, dodał.

Brutalne rozprawianie się $\mathrm{z}$ uczestnikami rajdów nie tylko nie zniechęciło ich, lecz wręcz przeciwnie, mobilizowało wciąż nowe osoby do walki. Czarnoskórych Amerykanów nie odstraszały nawet aresztowania i osadzanie $\mathrm{w}$ więzieniach o podwyższonym rygorze, gdzie strażnicy oblewali ich zimną wodą pod wysokim ciśnieniem i stosowali inne, równie dotkliwe metody. Rajdy zakończyły się dopiero we wrześniu 1961 roku, gdy Międzystanowa Komisja Handlowa (Interstate Commerce Commission) zabroniła przedsiębiorstwom kolejowym i autobusowym korzystania z dworców, na których obowiązywała segregacja.

Przez rok - aż do września 1962 roku, kiedy to James Meredith ubiegał się o przyjęcie na biały uniwersytet na południu kraju (University of Mississippi), John Kennedy nie przedsięwziął żadnych kroków w kwestii praw obywatelskich. Jednak dzięki zdecydowanej postawie Mereditha oraz zaangażowaniu się uniwersytetów w toczącą się walkę o zniesienie segregacji rasowej, sytuacja zmieniła się diametralnie. Prawa obywatelskie znalazły się wśród priorytetów polityki amerykańskiego prezydenta.

Pomimo zasług Mereditha dla ojczyzny - dziesięcioletniej służby w US Air Force - odmówiono mu przyjęcia na uczelnię, gdyż był czarny. Doszło do zamieszek, w wyniku których życie straciły dwie osoby, a 375 osób zostało ran-

\footnotetext{
3217 kwietnia 1961 roku oddział emigrantów kubańskich, przeszkolony i wyposażony w broń przez Stany Zjednoczone wylądował na Kubie w Zatoce Świń. Niezorientowane w sytuacji na Kubie służby CIA przewidywały, że przeciwko Fidelowi Castro wybuchnie powstanie. Tak się jednak nie stało. Inwazja napotkała zaciekły opór Kubańczyków, a cała operacja zakończyła się porażką po czterech dniach.

33 J. Farmer, Lay Bare the Heart: An Autobiography of the Civil Rights Movement, Texas Christian University Press, 1986, s. 206.
} 
nych $^{34}$. Prezydent Kennedy zaczął poważnie obawiać się, że zaistniała sytuacja może przyczynić się do pogorszenia wizerunku Stanów Zjednoczonych na arenie międzynarodowej. W swoim przemówieniu, nadawanym przez radio i telewizję dnia 30 września 1962 roku, prezydent nawoływał do przywrócenia porządku na terenie uniwersytetu, odwołując się do poczucia przyzwoitości obywateli Mississippi. „Oczy narodu i całego świata skierowane są na was i na nas wszystkich” - przekonywał Kennedy ${ }^{35}$. Raz jeszcze prezydent udowodnił, że w jego odczuciu prawa obywatelskie powinny być rozważane w kontekście polityki zagranicznej. Takie postawienie sprawy przez prezydenta nie przemawiało do zwolenników segregacji ze stanów południowych. Najwyraźniej nie byli oni skłonni do rezygnacji z dotychczasowego stylu życia na rzecz poprawy wizerunku Stanów Zjednoczonych za granicą. Argument, że rozruchy na tle rasowym w USA wywołają krytykę ze strony Związku Radzieckiego, co zresztą miało miejsce, nie znalazł także zrozumienia wśród czarnych działaczy, którzy nie aprobowali podporządkowania walki o prawa obywatelskie kwestiom zimnowojennym. Należy więc jednoznacznie stwierdzić, że zarówno wśród białych ekstremistów z Południa, jak i czarnych zwolenników desegregacji, postrzeganie przez Kennedy'ego sprawy Mereditha jako elementu polityki zagranicznej, nie znalazło uznania.

Sytuacja była trudna. Dopiero wsparcie 500 szeryfów i 3000 żołnierzy sił federalnych zapewniło zarejestrowanie się Mereditha w charakterze studenta uniwersytetu. Wydarzenia z Mississippi stanowiły niejako powtórzenie krytykowanego przez Kennedy'ego scenariusza z Little Rock, kiedy to Dwight D. Eisenhower zdecydował się na rozwiązanie konfliktu właśnie za pomocą sił federalnych. Choć w końcu doszło do integracji rasowej zarówno na University of Mississippi, jak i innych uniwersytetach na Południu, w dużej mierze miała ona charakter symboliczny, gdyż przez wiele jeszcze lat jedynie nieliczni czarni studenci zdobywali wiedzę w murach tych uczelni ${ }^{36}$.

O wydarzeniach z Mississippi szeroko pisała prasa na całym świecie. Po interwencji wojsk federalnych trafiały one nawet na pierwsze strony gazet. Komentarze były zróżnicowane w tonie, przeważały jednak głosy aprobaty dla decyzji prezydenta. Włoski dziennik Il Popolo donosił: Kennedy nigdy przedtem nie zastugiwat na większy podziw za swoja odwage politycznq. Niemiecki Westfaelische Rundschau pisał: Prezydent dał jasno do zrozumienia, że nie zamierza

\footnotetext{
34 Szerzej o wydarzeniach z Mississippi patrz: RSC, President John F. Kennedy's Office Files 1961-1963, Part 4, Reel 9.

35 JFKL, Pre-Presidential Papers, Box 912, Radio and Television Report to the Nation on the Situation at the University of Mississippi, September 30, 1962.

36 T. Branch, Parting the Waters: America in the King Years, 1954-1963, New York, Simon \& Schuster, 1988, s. 669; W. Lord, The Past That Would Never Die, New York, Harper \& Row, 1993, s. 196-197.
} 
wchodzić $w$ żadne układy polityczne $z$ rasistowskimi fanatykami. Rozsadni biali z Południa oraz Murzyni będa mu za to wdzięczni ${ }^{37}$.

Decyzja Kennedy'ego o rozstrzygnięciu konfliktu za pomocą sił federalnych spotkała się ze zrozumieniem ze strony innych narodów, a postawa i poczynania południowych ekstremistów zostały stanowczo skrytykowane, zwłaszcza przez dzienniki afrykańskie i azjatyckie. Indyjski Mail informował: Pocieszający jest fakt, że pan Barnett i jemu podobni przegrywaja swoja walkę. Nie tylko wojsko federalne, ale opinia świattych obywateli Stanów Zjednoczonych przeciwstawiaja się ich obskurantyzmowi. Tunezyjski Al-Amal pisał: W 1962 roku segregacja rasowa na południu Stanów Zjednoczonych pozostaje jak tragiczny anachronizm, podczas gdy nastęuje dekolonizacja całego świata. Afrykańskie i azjatyckie dzienniki stwierdzały również jednoznacznie, że Stany Zjednoczone, które nie zdołały uporządkować kwestii rasowych we własnym kraju, nie powinny zajmować się ingerencją w sprawy innych państw. Najdobitniej wyraził to izraelski dziennik Sawt al-Urba: Ten, kto nie potrafi obronić wolności w swoim własnym kraju, niegodny jest jej obrony w innych częściach świata ${ }^{38}$.

W przededniu setnej rocznicy podpisania Proklamacji Emancypacji, znoszącej niewolnictwo Murzynów, 15 października 1962 roku obrońcy praw obywatelskich wystosowali do prezydenta Kennedy'ego oświadczenie dotyczące sytuacji czarnej ludności w Stanach Zjednoczonych. Konieczność interwencji sił federalnych w sprawie Mereditha określona została w dokumencie jako dobitny dowód nienaturalnej, rozpaczliwej $i$ wyobcowanej pozycji czarnej ludności w społeczeństwie amerykańskim ${ }^{39}$. Autorzy dokumentu jednoznacznie stwierdzili, że nadal czarni Amerykanie spychani byli poza główny nurt życia kraju, nie utrzymywali normalnych relacji z białą społecznością i nigdzie, poza swoimi kościołami, nie czuli się swobodnie, a działo się tak jedynie z powodu koloru ich skóry. By przyczynić się do poprawy sytuacji czarnych Amerykanów w Stanach Zjednoczonych, postulowano o założenie National Intercultural Center (Narodowego Centrum Międzykulturowego), z siedzibą w Nowym Jorku i z oddziałami w innych miastach. W centrum obrońcy praw obywatelskich mieli przeprowadzać badania nad statusem czarnych obywateli Stanów Zjednoczonych i szukać sposobów na polepszenie ich położenia ${ }^{40}$.

Choć autorzy oświadczenia zwrócili się bezpośrednio do prezydenta o poparcie ich projektu, nie uczynił on tego, wyjaśniając, że nie nadszedł jeszcze

37 RSC, President John F. Kennedy's Office Files, 1961-1963, Part 3, Reel 27, Media Comment on the Mississippi Crisis.

38 Ibidem.

39 RSC, Civil Rights during the Kennedy Administration, 1961-1963, Part I, Reel 3, „A Statement Addressed to President John F. Kennedy Prior to the Centennial of the Emancipation Proclamation, January 1, 1963".

40 Ibidem. 
odpowiedni na to czas. W notatce z 31 stycznia 1963 roku, Louis Martin, czarny doradca Kennedy'ego w kwestiach praw obywatelskich, nawiązując do obietnic prezydenta z kampanii wyborczej, ostrzegał go, że Murzyni są na granicy buntu, i że poprzez swoje działania stwarzać będą sytuacje wymagające interwencji zarówno sił stanowych, jak i federalnych ${ }^{41}$. By załagodzić sytuację, Kennedy zapowiedział zorganizowanie w Białym Domu uroczystego przyjęcia dla przywódców murzyńskich. Odbyło się ono 12 lutego 1963 roku - w rocznicę urodzin Abrahama Lincolna. Wzięło w nim udział około ośmiuset osób. Zdaniem Louisa Martina, do Białego Domu tego jednego dnia przybyło więcej przedstawicieli ludności murzyńskiej, niż to miało miejsce w stupięćdziesięcioletnim okresie poprzedzającym ten wyjątkowy dzień. W ostatniej chwili powiadomiono gości, że prezydent i pierwsza dama czekać na nich będą przy południowo-zachodnim wejściu, a nie jak to wcześniej planowano - przy wschodnim. Uzasadniono to chęcią osobistego przywitania gości przez prezydencką parę w części prywatnej Białego Domu. Wiele osób odebrało to jako specjalne wyróżnienie, faktycznie jednak, był to zabieg mający na celu uniknięcie możliwości sfotografowania czarnych Amerykanów w oficjalnych pomieszczeniach rezydencji ${ }^{42}$.

O ile oficjalne przywitanie gości odbyło się bez większych zakłóceń, problem pojawił się później. Na przyjęcie przybył Sammy Davis Jr., czarny piosenkarz i tancerz ze swoją białą żoną, Szwedką, Mai Britt. Tego typu małżeństwa zazwyczaj nie spotykały się z akceptacją białych Amerykanów, nie dziwi więc fakt, że Kennedy nie szczędził wysiłków, by zapobiec sfotografowaniu Sammy Davisa i Mai Britt jako pary. Prezydent prosił nawet swoją żonę, Jacqueline Kennedy, o pomoc w odprowadzeniu Szwedki na bok, gdy będzie robione oficjalne zdjęcie. Pani Kennedy stanowczo odmówiła ${ }^{43}$. Choć trudno w to uwierzyć, zabiegi prezydenta mające na celu uniknięcie rozgłosu, z jakim normalnie spotkałoby się przyjęcie wydane w Białym Domu na osiemset osób, odniosły oczekiwany skutek. Prasa niewiele pisała o uroczystości, a jeśli już zamieszczono na ten temat artykuł, skrzętnie pomijano obecność czarnych gości, skupiając się raczej, jak to uczyniła Chicago Daily Tribune, na fakcie złożenia hołdu republikańskiemu prezydentowi, Abrahamowi Lincolnowi, przez demokratycznego prezydenta, Johna Kennedy'ego ${ }^{44}$. Należy jednak nadmienić, że 13 lutego 1963 roku The Washington Post opublikował zdjęcie z uroczystości, na którym można było zobaczyć prezydencką i wiceprezydencką parę $\mathrm{w}$ towarzystwie jedenastu czarnych działa-

41 JFKL, Sorensen Papers, Box 30, notatka Louisa Martina do Theodora Sorensena z 31 stycznia 1963.

42 Wywiad Louisa Martina z Richardem Reevesem, [w:] R. Reeves, President Kennedy..., s. 464.

43 Ibidem.

44 Tribute, „Chicago Daily Tribune”, 13 lutego 1963, s. 1. 
czy. Znamienne jest jednak to, Ze dziennik zamieścił fotografię w dziale „For and About Women" (Dla i o kobietach) ${ }^{45}$.

Uroczystość, która odbyła się w Białym Domu 12 lutego 1963 roku, stanowiła kolejną okazję do przypomnienia nie tylko prezydentowi faktów dotyczących sytuacji czarnej ludności w Stanach Zjednoczonych. W 264-stronicowym raporcie na ten temat, przygotowanym przez Komisję Spraw Obywatelskich, można było przeczytać o „wyzwoleniu bardziej fikcyjnym niż realnym”" ${ }^{46}$. The New York Times donosił o ciężkim położeniu czarnego Amerykanina, który był pozbawiony prawa wyborczego, wykluczony z życia publicznego, przypisany do gorszych $i$ oddzielnych szkót, gromadzony w getta, odsyłany do tylnej części autobusu, traktowany niesprawiedliwie $w$ sadach $i$ narażony na segregacje $w$ chorobie, modlitwie $i$ śmierci $^{47}$.

Dopiero w dwa lata po objęciu urzędu prezydenta, John Kennedy wystąpił ze swoją pierwszą inicjatywą legislacyjną w sprawie praw obywatelskich. 28 lutego 1963 roku prezydent zaprezentował w Kongresie projekt ustawy dotyczący praw wyborczych. Zgodnie z podstawowym założeniem projektu, ukończenie sześciu klas szkoły podstawowej miało gwarantować prawo głosu. Chodziło o przeciwstawienie się stosowanym na Południu praktykom sprawdzania piśmienności obywateli poprzez czytanie i interpretowanie Konstytucji Stanów Zjednoczonych. Godziło to bezpośrednio w potencjalnych czarnych wyborców, którzy rzadko kiedy byli w stanie sprostać takiemu zadaniu. Projekt Kennedy'ego uznany został przez działaczy na rzecz praw obywatelskich za niewystarczający. Po dwóch latach oczekiwań na jakąkolwiek inicjatywę legislacyjną ze strony prezydenta, uważali oni, że mają prawo do bardziej wszechstronnego projektu, gwarantującego położenie kresu dyskryminacji w miejscach użyteczności publicznej, desegregację szkół publicznych i ochronę czarnych wyborców. Jednak Kennedy utrzymywał, że szersza inicjatywa w zakresie praw obywatelskich nie zostanie poparta przez Kongres. Prezydent zapewniał senatora Huberta H. Humphreya, jednego z najgorliwszych obrońców praw obywatelskich w partii demokratycznej, że z pewnością zarekomenduje w Kongresie odpowiedni projekt, kiedy tylko pojawi się szansa, że zostanie on przyjęty ${ }^{48}$. Jednak działacze na rzecz praw obywatelskich nie chcieli już dłużej czekać. W swojej książce zatytułowanej Why We Can't Wait (Dlaczego nie możemy czekać) Martin Luther King Jr. pisał, że czarna społeczność zbyt długo powstrzymywała się od egzekwowania zobowiązań rządowych, gdyż zapewniano ją, że jeszcze nie nadszedł odpowiedni czas.

\footnotetext{
45 „The Washington Post”, 13 lutego 1963 r., s. 21.

46 Fragmenty raportu zostały przedrukowane przez „The New York Times”, 13 lutego 1963, s. 8.

47 „The New York Times”, 13 lutego 1963, s. 8.

48 JFKL, Oral History Interview with Hubert H. Humphrey, August 17, 1971, conducted by Joe B.. Frantz for the Lyndon B., Johnson Library.
} 
Było to tym bardziej bolesne, że prezydent deklarował podjęcie wszelkich niezbędnych środków zaradczych, by bronić wolności i równości za granicą, podczas gdy wolność i równość obywateli Stanów Zjednoczonych wydawała się, z jego punktu widzenia, sprawą o mniejszym znaczeniu ${ }^{49}$.

Martin Luther King Jr. nie wziął udziału w uroczystym przyjęciu zorganizowanym w rocznicę urodzin Abrahama Lincolna. Przebywał on wówczas na Jamajce, gdzie odpoczywał i jednocześnie opracowywał tak zwany Projekt C, dotyczący kampanii na rzecz praw obywatelskich w jednym z najbardziej dotkniętych segregacją mieście Południa, Birmingham w stanie Alabama. Projekt C miał przebiegać trzystopniowo. Najpierw miała nastąpić aktywizacja czarnego społeczeństwa miasta. Następnie zakładano doprowadzenie do bojkotu ekonomicznego, a w końcowym etapie planowano marsze ulicami Birmingham. King przewidywał, że w trakcie realizacji projektu dojdzie do masowych aresztowań, co chciał wykorzystać do przyciągnięcia uwagi szerokiej opinii publicznej ${ }^{50}$.

Projekt C zaczęto wcielać w życie 3 kwietnia 1963 roku, jednak nie nabrał on planowanego przez jego autora rozmachu. Wręcz przeciwnie, po miesiącu demonstracji, wielu aktywistów ruchu znalazło się w więzieniu. Część czarnej społeczności niechętnie odnosiła się do projektu, a prasa stopniowo traciła zainteresowanie kwestią praw obywatelskich. W związku z narastająca krytyką, nie tylko w odniesieniu do samego projektu, ale również jego autora, 16 kwietnia 1963 roku Martin Luther King Jr. napisał swój słynny „List z więzienia w Birmingham" "51. W tym liście, kierowanym do ośmiu duchownych z Alabamy, pastor $\mathrm{z}$ wielkim zaangażowaniem pisał o konieczności stosowania biernego oporu, taktyki stosowanej z powodzeniem przez samego Ghandiego wobec Brytyjczyków. King był przekonany, że doskonale sprawdzi się ona również w walce z prześladowaniami na tle rasowym w mieście, które powszechnie kojarzyło się $\mathrm{z}$ praktykami segregacyjnymi. $\mathrm{W}$ związku $\mathrm{z}$ tym, że Projekt $\mathrm{C}$ nie przynosił oczekiwanych rezultatów, liderzy ruchu zdecydowali się na ryzykowne posunięcie - 2 maja 1963 roku zorganizowali marsz dzieci. Pod koniec dnia 500 młodych ludzi aresztowano, należy jednak zaznaczyć, że nie doszło do przejawów przemocy ze strony miejscowych władz. Dopiero 3 maja 1963 roku, w trakcie podobnego marszu z udziałem dzieci, władze stanowe zarządziły rozproszenie demonstracji (zarówno uczestników marszu, jak i obserwujących ich dorosłych) za pomocą psów policyjnych i strumieni wody pod wysokim ciśnieniem. Podjudzane psy rzucały się na ludzi, a woda podcinała nogi demonstrantów, toczyła

49 Szerzej na ten temat patrz: M. Luther King, Jr., Why We Can't Wait, New York, Harper Collins, 1964.

50 G. E. Pauley, The Modern Presidency \& Civil Rights. Rhetoric on Race from Roosevelt to Nixon, Texas A\&M University Press College Station, 2001, s. 123.

51 The Estate of Martin Luther King, http://www.stanford.edu/group/King/Docs/birmingham.html, Letter from Birmingham Jail, April 16, 1963. 
ich ulicą i rzucała na okoliczne budynki. Zdjęcia pojawiające się później w prasie i relacje telewizyjne wprawiły w osłupienie nie tylko Amerykanów ${ }^{52}$. Sceny przemocy nie mogły pozostać bez oddźwięku w nowo wyzwalających się krajach, gdzie Stany Zjednoczone prowadziły z Moskwą batalię o „serca i umysły” ich obywateli. W sytuacji, gdy kraje te nie opowiedziały się jeszcze po żadnej ze stron, zajścia z Birmingham z pewnością nie przyczyniły się do wciągnięcia ich w strefę amerykańskich oddziaływań.

Ustosunkowując się do wydarzeń z Birmingham, Kennedy twierdził, że nie mógł interweniować, gdyż rozwiązanie tego konfliktu leżało w gestii władz stanowych. Prezydent podkreślił jednocześnie, że uczyni wszystko, by drogą negocjacji doprowadzić go zażegnania konfliktu. Nie na taką reakcję czekali czarni przywódcy. Martin Luther King Jr., wypowiadając się przed kamerami telewizyjnymi, stwierdził: Nie krytykuję prezydenta, ale będziemy musieli mu pomóc. Nadszedt czas na zajęcie przez rzad federalny jednoznacznego stanowiska $w$ sprawie segregacji rasowej $w$ Stanach Zjednoczonych ${ }^{53}$. W odpowiedzi na słowa Kinga, Biały Dom mógł jedynie wyrazić nadzieję, że dzięki negocjacjom toczącym się od 5 maja 1963 roku, w Birmingham w końcu zostanie osiągnięte porozumienie. Doszło do niego 8 maja 1963 roku i na ten właśnie dzień zaplanowana została konferencja prasowa w Białym Domu. Ku wielkiemu rozczarowaniu zwolenników desegregacji rasowej, prezydent nie dostrzegł moralnego wymiaru wydarzeń z Birmingham i po raz kolejny rozpatrywał je w kategoriach pogorszenia się wizerunku Stanów Zjednoczonych na świecie. Podczas konferencji z 8 maja 1963 roku Kennedy określił zajścia z Birmingham jako spektakl, który poważnie zaszkodzit reputacji zarówno samego Birmingham jak i catego kraju ${ }^{54}$.

Uporczywe przedstawianie przez prezydenta walki o prawa obywatelskie jako działalności dyskredytującej ojczyznę na arenie międzynarodowej, skłoniło Kinga do sarkastycznego tonu. Podczas mszy 10 maja 1963 roku stwierdził on: Stany Zjednoczone martwiq się o swój wizerunek. Kiedy sytuacja zaczęła się tu rozwijać, pan Kennedy byt zaniepokojony, ponieważ pan Kennedy walczy o umysty $i$ serca ludzi $w$ Azji i Afryce - jakiegoś miliarda ludzi na świecie - a oni nie będa szanować Stanów Zjednoczonych, jeśli te pozbawia swoich mężczyzn

52 Zajścia z Birmingham na żywo relacjonowały CBS, NBC i ABC, relacje prasowe pojawiały się m.in. [w:] Squeeze in the South, „Time”, 3 maja 1963, s. 23; The Resounding City, „The New York Times", 4 maja 1963, s. 12; patrz również: T. Branch, Parting the Waters..., s. 734-755, D. J. Garrow, Bearing the Cross: Martin Luther King, Jr., and the Southern Christian Leadership Conference, New York, William Morrow, 1986, s. 241-248; S. B. Oates, Let the Trumpet Sound: The Life of Martin Luther King, Jr., New York, Harper \& Row, 1982, s. 212-232.

53 Tekst telewizyjnej przemowy Martina Luthera Kinga został wydrukowany w „Birmingham News", 8 maja 1963, s. 1-2.

54 RSC, President John F. Kennedy's Office Files 1961-1963, Part 1, Reel 22, President John F. Kennedy's News Conference No. 55, May 8, 1963. 
i swoje kobiety podstawowych praw, ze względu na kolor ich skóry. Pan Kennedy wie o tym ${ }^{55}$. Ton wypowiedzi Kinga nawołujący Kennedy'ego do zajęcia właściwego stanowiska w kwestii praw obywatelskich stawał się coraz śmielszy. Czarny przywódca dawał prezydentowi do zrozumienia, że jeśli ten nie poprze jednoznacznie ich staran, zwróci się o pomoc do republikanów, a w pierwszej kolejności do Nelsona Rockefellera. Po nagłośnieniu wydarzeń z Birmingham, także biali Amerykanie (wśród nich wiele znaczących osób publicznych, takich jak wybitny i bardzo wpływowy publicysta, Walter Lippmann) zaczęli odnosić się z większym zrozumieniem do konieczności przyspieszenia desegregacji. Co więcej, sugerowano, iż to właśnie prezydent powinien odegrać decydującą rolę $\mathrm{w}$ tym procesie ${ }^{56}$. Szeroko zakrojona krytyka wydarzeń z Birmingham, poparta żądaniami obrońców praw obywatelskich i konkretnymi oczekiwaniami ze strony, neutralnych do tej pory lub wręcz wrogich przemianom, białych Amerykanów zmusiła Kennedy'ego do dostrzeżenia moralnego wymiaru problemu. Prezydent zrozumiał, że nie może w dalszym ciągu uchylać się od konkretnych posunięć, gdyż sprawa sama się nie rozwiąże. Dlatego też 22 maja 1963 roku Kennedy ogłosił na konferencji prasowej, że Biały Dom rozważa nowe projekty legislacyjne w zakresie praw obywatelskich. W celu zapewnienia odpowiedniego poparcia dla uchwalenia projektu, w maju 1963 roku prokurator generalny, Robert Kennedy, przeprowadził serię spotkań, w których udział wzięli zarówno biali Amerykanie, jak i czarni liderzy ruchu na rzecz praw obywatelskich ${ }^{57}$.

Także spotkanie prezydenta z najważniejszymi urzędnikami państwowymi z 1 czerwca 1963 roku służyło omówieniu tych zagadnień. Podczas spotkania prokurator generalny, Robert Kennedy, postulował uchwalenie kompleksowego projektu o prawach obywatelskich, co jednak nie spotkało się z powszechną akceptacją ze strony uczestników spotkania. Największe kontrowersje pojawiły się wokół możliwości włączenia do projektu prawa, które zezwalałoby Departamentowi Sprawiedliwości na wytoczenie sprawy w sytuacji, gdy Murzyni skarżyli się na nierówne traktowanie $\mathrm{w}$ ramach prawa federalnego.

Pomimo toczących się prac legislacyjnych, w kraju dochodziło do kolejnych wystąpień na tle rasowym. 28 maja 1963 roku rozpoczęły się demonstracje (marsze i ,sit-ins”) w Jackson w stanie Mississippi. Doszło tam do pobicia, pokopania, oblewaniem musztardą i ketchupem oraz posypywania solą i cukrem białego profesora socjologii oraz trójki czarnych studentów, którzy chcieli być obsłużeni w barze w sklepie Woolworth ${ }^{58}$.

55 Fragment kazania Martina Luthera Kinga w: Richard, Lischer, The Preacher King,. Marti Luther King Jr. and the Word That Moved America, Oxford University Press, 1997, s. 167.

56 G. E. Pauley, The Modern..., s. 125.

57 R. Reeves, President Kennedy..., s. 501.

58 O wydarzeniach w Jackson pisano m.in. w The Revolution, „The New York Times”, 1 czerwca 1963, s. 2; The Boycott Road to Rights, „Time”, 7 czerwca 1963, s. 18. 
Po wydarzeniach w Jackson, King chciał się widzieć z Kennedym, ale mimo usilnych starań ze strony czarnego działacza, do spotkania nie doszło ${ }^{59}$. Kennedy nie ustawał jednak w wysiłkach mających na celu zażegnanie konfliktu. Zarówno on sam, jak i prokurator generalny przeprowadzili wiele rozmów telefonicznych $\mathrm{z}$ gubernatorem Allenem Thompsonem oraz $\mathrm{z}$ innymi gubernatorami i burmistrzami z Południa ${ }^{60}$. Sytuacja nie była jednak łatwa do opanowania ani w Jackson, ani w innych miastach. W Tallahassee na Florydzie, policja rozpędzała demonstrujących gazem łzawiącym. Także w Tuscaloosa, w stanie Alabama wzrastało napięcie, gdyż dwoje czarnych młodych ludzi planowało zapisanie się na miejscowy uniwersytet. Gubernator tego stanu, George Wallace, słynął ze swoich rasistowskich poglądów. To on właśnie był autorem sloganu: „Segregacja dziś! Segregacja jutro! Segregacja zawsze!”. Gdy ubiegał się o stanowisko gubernatora, przyrzekał stanąć w bramie budynku uniwersytetu i osobiście bronić dostępu do niego czarnym studentom, jeśli zajdzie taka konieczność. Nic więc dziwnego, że w sprawie zapisania dwojga czarnych studentów na University of Alabama, był nieustępliwy. W przemowie telewizyjnej z 10 czerwca 1963 roku gubernator Alabamy zapewnił, że nie ugnie się pod naporem sił federalnych, usiłujących doprowadzić do desegregacji uniwersytetu. Przekonywał również, że potrafi utrzymać porządek na terenie stanu ${ }^{61}$. Choć początkowo trudno było przewidzieć, jak potoczą się wydarzenia w Tuscaloosa, dzięki przejęciu stanowej Gwardii Narodowej Alabamy przez siły federalne 10 czerwca 1963 roku $^{62}$, dzień później udało się doprowadzić do zapisania czarnych studentów na uniwersytet bez rozlewu krwi. Tego samego dnia, w swoim słynnym przemówieniu telewizyjnym, oglądanym przez miliony Amerykanów, John Kennedy potraktował prawa obywatelskie w kategoriach moralnych. Mam nadzieję, że każdy Amerykanin, niezależnie od tego, gdzie mieszka, zatrzyma się na chwile i rozważy $w$ swoim sumieniu ten incydent $i$ inne podobne, nawoływał Kennedy. W dalszym fragmencie przemówienia stwierdził wprost: Mamy tu do czynienia przede wszystkim $z$ kwestiq moralnq. Następnie prezydent apelował o konstruktywne podejście do rozwiązania problemu: Tak więc znaleźliśmy się w obliczu moralnego kryzysu, jako kraj i jako naród. Nie można mu zapobiec represyjnymi działaniami policji. Nie można go pozostawić wzmagającym się demonstracjom ulicznym. Nadszedt czas, by podjać działania $w$ Kongresie, $w$ poszczególnych stanach $i$ lokalnych

59 JFKL, White House Central Subject Files, Box 363, telegram Martina Luthera Kinga do Johna Kennedy'ego, 30 maja 1963.

60 Transkrypty z przeprowadzonych rozmów można znaleźć w: JFKL, Presidential Recordings.

61 G. A. Pauley, The Modern..., s. 127.

62 RSC, President John F. Kennedy's Office Files, 1961-1963, Part 4, Reel 3, Executive Order No. 11118, Providing Assistance for Removal Obstructions of Justice in the State of Alabama, September 10, 1963, 
ciałach legislacyjnych, a nade wszystko, w naszym codziennym życiu. Wielkie zmiany sa blisko ${ }^{63}$. Przemówienie Kennedy'ego rozbudziło wielkie nadzieje czarnych obywateli na radykalne zmiany w ich sytuacji życiowej.

Prasa amerykańska pozytywnie wypowiadała się o wystąpieniu prezydenta. Pojawiające się artykuły podkreślały osobisty charakter wypowiedzi Kennedy'ego oraz jego zaangażowanie ${ }^{64}$. O doniosłości przemówienia z 11 czerwca 1963 roku świadczy fakt, że „Time” nazwał je „być może najważniejszym, jakie Kennedy kiedykolwiek wygłosił" ${ }^{65}$. W tym dniu John Kennedy udowodnił, że wart był zaufania, jakim obdarzyły go ważne osoby publiczne (np. Eleanor Roosevelt) jeszcze w trakcie kampanii wyborczej. Była pierwsza dama Stanów Zjednoczonych początkowo niechętnie odnosiła się do Kennedy'ego, z czasem jednak uznała, że John Kennedy to człowiek, który chce pozostawić po sobie świadectwo, nie tylko pomagajac swoim rodakom, ale i całej ludzkościb.

Można by przypuszczać, że przemówienie prezydenta położy kres zamieszkom na tle rasowym. Tak jednak się nie stało, te same dzienniki i czasopisma, które wychwalały wystąpienie Kennedy'ego, w dniu następnym informowały o nowych zajściach ${ }^{67}$. Sytuacja pozostawała nieustabilizowana, pomimo prac legislacyjnych trwających nad nowym rozległym projektem o prawach obywatelskich $^{68}$, przedstawionym przez Kennedy'ego w Kongresie 19 czerwca 1963 roku. W celu poparcia projektu, w Białym Domu zorganizowano spotkania z białymi Amerykanami, którzy mogli mieć wpływ na budowanie porozumienia z czarnymi obywatelami Stanów Zjednoczonych. Co tydzień prezydent, wiceprezydent i prokurator generalny przekonywali zaproszonych gości - duchowieństwo, prawników, nauczycieli, wydawców gazet - o potrzebie działania na rzecz desegregacji ${ }^{69}$. Nieprzypadkowo zabiegano o poparcie inicjatywy przez wpływowych obywateli Stanów Zjednoczonych. Ich zaangażowanie miało zagwarantować dotarcie do szerokich rzesz Amerykanów, zapewniając w ten sposób sukces przedsięwzięcia.

63 RSC, President John F. Kennedy's Office Files 1961-1963, Part 4, Reel 3, Television Address by John F. Kennedy of June 11, 1963, s. 232.

64 Artykuły nawiązujące do przemówienia Kennedy'ego z 11 czerwca 1963 roku oraz dokumentujące zachodzące zmiany w procesie desegregacji, pojawiły się m.in. w: „The New York Times”, „Time”, „New Yorker”.

65 „The President's Address”, Time, 12 czerwca 1963, s. 4.

66 Eleanor Roosevelt cytowana, [w:] H. Parafianowicz, Eleanor Anna Roosevelt (1884-1962).

W cieniu wielkiego męża, Warszawa: Wydawnictwa Uniwersytetu Warszawskiego, 2000, s. 216.

67 Patrz: Two Seized in Gadsden, Ala., After 300 March in Protest, „The New York Times”, 12 czerwca 1963, s. 10; Jackson Negroes Clubbed as Police Quell Marchers, „The New York Times", 13 czerwca 1963, s. 14.

68 Projekt miał gwarantować desegregację miejsc publicznych, w tym szkół publicznych, oraz zapewnić ochronę czarnych wyborców.

69 RSC, President John F. Kennedy’s Office Files 1961-1963, Part 4, Reel 3. 
Pomimo starań rządu federalnego, mającego na celu zapewnienie ludności murzyńskiej zrównania z białymi obywatelami w kwestii praw obywatelskich, na ulicach amerykańskich miast i miasteczek nie było spokoju. Nieustannie dochodziło tu do zamieszek, a na 28 sierpnia 1963 roku zaplanowano marsz na Waszyngton.

W marszu protestacyjnym wzięło udział dwieście tysięcy czarnych i białych Amerykanów. Była to pokojowa manifestacja zorganizowana przez Martina Luthera Kinga. Odbyła się ona bez żadnych incydentów - tłumy przemaszerowały od Washington Monument do Lincoln Memorial. Przywódcy ruchu na rzecz obrony praw człowieka wystąpili ze swoimi przemówieniami. W jednym z nich wypowiedziane zostały słowa, które do dzisiaj pamiętają ludzie na całym świecie. Miałem sen - mówił pastor King - na wzgórzach Georgii synowie bytych niewolników i synowie byłych właścicieli niewolników zdołaja zasiąść wspólnie przy stole braterstwa. Przed zebranymi tłumami King roztoczył wizję kraju, w którym nie będzie miejsca dla jakichkolwiek przejawów dyskryminacji i nawiązał do dnia, kiedy to „wszystkie dzieci Boga”, niezależnie od rasy, wyznania, wezmą się za ręce i zaśpiewają: „Nareszcie wolni!”70.

28 sierpnia po południu, organizatorzy marszu spotkali się z prezydentem w Białym Domu. Kennedy pogratulował Kingowi płomiennego przemówienia, a następnie dyskutowano na temat możliwości poparcia projektu ustawy o prawach obywatelskich. Dokładnie obliczono liczbę głosów, które mogłyby zadecydować o przyjęciu projektu i okazało się, że nie było podstaw do zbytniego optymizmu w tej kwestii. Zdecydowanie nie można było liczyć na demokratów z Południa, a bez ich poparcia projekt nie miał szans. Jednak działacze na rzecz praw obywatelskich zdążyli się już przyzwyczaić do ogromnego wysiłku i poświęcenia, którymi okupione były nawet najmniejsze kroki na drodze do zrównania w prawach obywatelskich. Teraz też nie zamierzali się poddać. Philip A. Randolph, jeden z przywódców ruchu stwierdził: To będzie krucjata. I sądze, że nikt nie potrafi poprowadzić jej lepiej niż pan, panie prezydencie ${ }^{71}$. W ten sposób Randolph dał Kennedy'emu do zrozumienia, iż działacze na rzecz praw obywatelskich oczekują od niego pełnego zaangażowania oraz wyraźnego opowiedzenia się po ich stronie.

Trzy ostatnie miesiące administracji Johna Kennedy'ego nie przyniosły zasadniczych zmian w procesie legislacyjnym - nie doszło do uchwalenia ustawy o prawach obywatelskich. Należy jednak pamiętać, że to właśnie podczas prezydentury Johna Kennedy'ego postawione zostały kolejne kroki na drodze do jej

70 Cytat z przemówienia Martina Luthera Kinga: „The New York Times”, 29 sierpnia 1963, s. 1; relacje z marszu: T. Branch, Parting the Waters..., s. 877-882; S. B. Oates, Let the Trumpet Sound..., s. 184-253; „New Republic”, 14 września 1963.

71 JFKL, Presidential Recordings, Audiotape 108.2 
wejścia w życie, poczynając od rajdów wolności w 1961 roku, poprzez desegregację uniwersytetu w Mississippi we wrześniu 1962 i demonstracje w Birmingham wiosną 1963 roku, aż po marsz na Waszyngton 28 sierpnia 1963 roku.

To prawda, że Kennedy nie zaangażował się w obronę praw obywatelskich z pobudek moralnych i z pewnością jego poczynania nie miały charakteru misji. Stanął raczej w obliczu dokonujących się zmian w tym zakresie i to one właśnie zdominowały jego prezydenturę. Choć wielu działaczy krytykowało prezydenta za opieszałość legislacyjną i niedostrzeganie moralnego wymiaru walk o prawa obywatelskie, to dzięki jego poparciu możliwe było pokonywanie kolejnych barier na drodze ku zrównaniu białych i czarnych obywateli USA w prawach obywatelskich. Do uchwalenia ustawy o prawach obywatelskich doszło dopiero w 1964 roku, za kadencji Lyndona B. Johnsona.

\section{Fighting for civil rights - John F. Kennedy's unfinished mission?}

During John F. Kennedy's administration several important steps on the way to racial equality were undertaken. His presidency will always be associated with such events as: Freedom Rides of 1961, desegregation of the University of Mississippi in September 1962, demonstrations in Birmingham in the spring of 1963 or the famous March on Washington on August 28, 1963.

It is true that John F. Kennedy did not get involved in the protection of civil rights because of moral causes, and certainly, he did not consider it to be his mission. He rather had to face the changes that the US society was undergoing in this field in the early nineteen-sixties, changes that dominated his presidency. Numerous black activists criticized Kennedy for his legislative indolence and failing to recognize a moral dimension in the fight for civil rights. However, without the President's support, their efforts aiming at obliterating racial differences would have been useless. Moreover, without John F. Kennedy's involvement, the 1964 Act of Civil Rights, that went into effect during the Johnson administration, would not have been possible. 